\title{
非線形ばねを用いたボアホール用上下動地震計の特性
}

\author{
地震予知総合研究振興会* 鹿 熊 英 昭 ${ }^{\dagger}$ \\ 東京大学地震研究所** 笠 原 敬 司・小原一成 \\ 防災科学技術研究所 $* * *$ 汐見勝彦 \\ 中央大学理工学部 $* * * *$ 村奈嘉与一

\section{Characteristics of Borehole Vertical Seismometer Using a Nonlinear Spring}

\author{
Hideaki KAKUMA $^{\dagger}$
}

Association for the Development of Earthquake Prediction,

3-1, Tenno-dai, Tsukuba, Ibaraki 305-0006, Japan

Keiji Kasahara and Kazushige OBARA

Earthquake Research Institute, University of Tokyo, 1-1-1, Yayoi, Bunkyo-ku, Tokyo 113-0032, Japan

\section{Katsuhiko SHiomi}

National Research Institute for Earth Science and Disaster Prevention, 3-1, Tenno-dai, Tsukuba, Ibaraki 305-0006, Japan

\section{Yoichi MURANAKA}

Faculty of Science and Engineering, Chuo University, 1-13-27, Kasuga, Bunkyo-ku, Tokyo 112-8551, Japan

(Received April 23, 2010; Accepted March 2, 2012)

\begin{abstract}
A nonlinear spider spring with an initial displacement offset is used to suspend a mass with a coil or permanent magnet and to restore the force spring in order to miniaturize a borehole vertical seismometer with a low natural frequency. We investigate the response properties of the nonlinear spider spring, which remain unknown even though the seismometer adopting nonlinear spider spring is widely used. The relation between the initial offset and the spring constant is clarified for the first time: the spring constant is weakened with increasing initial offset. We confirmed that the flat spider spring has a nonlinear property (as does the spider spring with an offset), although it has previously been considered a linear spring. An analysis of limitations in the use of the seismometer revealed that the nonlinearity can be ignored if the seismometer is used under the condition of small displacement that is recommended by manufacturer.
\end{abstract}

Key words: Borehole vertical seismometer, Nonlinear spider spring, Zero-length spring, Initial displacement offset, Electromagnetic seismometer

\footnotetext{
*, *** 干305-0006 つくば市天王台 3-1

** \%113-0032 東京都文京区弥生 1-1-1

**** $=112-8551$ 東京都文京区春日 1-13-27

$\dagger$ 現所属: 中央大学理工学部
} 


\section{§1. はじめに}

自然地震観測では目的に応じて様々な地震計を使い分 けるが, 現在の高感度微小地震観測の分野では, 固有振 動数 $1 \mathrm{~Hz}$ の電磁式速度型地震計を利用するのが一般的 である。我が国における HES［萩原 (1966)］の完成や， Berknerの提言 [Press (1959)] を受けたプロジェクト VELA-UNIFORM [Lee et al. (2002)] による大規模アレ イ LASA [Green et al. (1965)], あるいは WWSSN [Oliver and Murphy (1971)] の短周期地震計として $1 \mathrm{~Hz}$ 速度型 地震計が採用された時期がほぼ一致することで明らかな ように, このタイプの地震計は, 1960 年代に微小地震 観測用高感度地震計の定番としての地位を確立した。

$1 \mathrm{~Hz}$ 速度型地震計が広く利用されている理由のひと つとして, エレクトロニクスの進歩により, 安定した観 測システムを構築することが可能となったことが挙げら れる。また，地震計の基幹部が，ばね，コイルおよび磁 石だけで構成されるという単純な構造のため, 長期間の 持続的観測が可能であること, 記録計のダイナミックレ ンジが狭かった時代でも，周期 2～8 秒に卓越する脈動 ノイズを避け, 高周波数成分に卓越する微小地震の高感 度観測が可能である，といった利点を挙げることが出来 る.

高感度微小地震観測を行う際，人間活動等に伴う地表 付近ノイズの影響を極力避ける必要がある。このため, 観測井（ボアホール）を掘削し，その孔底に地震計を設 置することが多いが, ボアホール設置用の固有振動数 1 $\mathrm{Hz}$ の地震計として, 地震探鉱用に開発された直動型地 震計が多用されている [例えば, Forbes et al. (1965)]. これは，探鉱用地震計が小さな円筒形構造をしているこ と，かつ丈夫であることが，ボアホール観測に適してい たためと考えられる。1970 年に，国立防災科学技術七 ンター（現，防災科学技術研究所．以下，防災科研）に より, $100 \mathrm{~m}$ 級の浅井戸観測システムが開発された [高 橋 (1970)]。この時, 微小地震観測用高感度地震計とし て, 米国 Mark Products（現 Sercel）社製の地震探鉱用 上下動地震計 L-4C（直径： $76 \mathrm{~mm}$ ）が採用された。また, $3000 \mathrm{~m}$ 級ボアホール（防災科研岩槻地殼活動観測施設） に抢ける高温環境下 $\left(86^{\circ} \mathrm{C}\right)$ での地震観測を実現するた めに，同地震計のコイルボビンを改良して使用した [高 橋 (1982)]。近年, 大規模に展開された防災科研高感度 地震観測網 Hi-net［例えば，汐見・他 (2009)］に扔いて も，800 ケ所を超えるボアホールで同型の地震計が利用 されている [Obara et al. (2005)]. 上下動地震計では, 重 力が作用する状態で振子の質量を支え，かつ中立点に保 持させるため, 予め初期変形を加えて非線形特性を持た せた非線形ダイヤフラムばねが採用されている，Fig. 1
に, Hi-net等で使用されている $1 \mathrm{~Hz}$ 上下動地震計の構 造図を示す。地震計の性能評価の指標として, 高調波共 振と波形のディストーションが良く用いられる[黒田・ 阿部 (1998)]。この地震計では, 非線形ダイヤフラムば ねを振子質量としてのコイルの上下に配置して運動方向 を制限することにより，高調波共振が抑制される。また， デュアルコイルとそれに対向するように磁気回路を配置 することで, 地震計としての各種性能を向上させ, ディ ストーションを低隇化している。これらの性能向上は, 1960 年代以降，地震探鉱測定システムのディジタル化 に向けた開発の促進や物理探査関係者らによって実施さ れた地震計出力振幅の線形性, 周波数特性, 耐久性等の 徹底した技術評価ならびに性能検査によるものである。 実際に, 房総半島に位置する防災科研の岩井北地殼活動 観測施設に 1970 年に設置された L-4C 地震計は, 現在 まで 40 年以上安定して稼動している。このことは，ば ね材として $\mathrm{BeCu}$ (ベリリウム銅）を使用したこと等, 設計過程での素材の選択や, 製造工程での熱処理（時効 硬化処理）など，当時の米国の技術水準の高さを示すも のであり，常温環境で使用する L-4C 地震計の設計・製 造技術は，ばね系を含め，当時までにほとんど確立され ていたと言える

一方，深層ボアホール等に扔ける上下動地震計につい ては，地震計を動作可能な状態にする姿勢制御，設置方 位測定，観測井孔壁への固定など，当時の様々な最先端 技術を結集して製作が進められたが，高温環境下に設置 されることの影響は時間とともに多くの課題を発生させ た [高橋 (1982)]。例えば, 当初は常温環境下で動作す る L-4C 地震計に対し，高温対策としてコイルの絶縁が 保持できる程度の簡単な改良を行ったが，観測中にコイ ルボビンに使用されている絶縁樹脂が加水分解・膨張粉 化して可動コイルが接触するなどの問題が生じたため, $100^{\circ} \mathrm{C}$ 程度でもこれが生じない非磁性の金属製コイルボ ビンが採用された，この対策によって，金属製コイルボ ビンに発生する渦電流により電磁ダンピングが加算され たため, シャント抵抗のみを使用する場合に比べて，比 較的低周波数である地震波の測定領域では出力電圧をよ り高く取れるという利点も生じた。

また，高温環境でばねの保持力が低下すると振子の中 立点位置が変動し, 振動特性が変化することが予測され るため，振子をマグネットの吸引力で引き上げる構造を 有している (Fig. 1)。この補正用マグネットは, 磁力に よる吸引力が振子系全体のばね定数に影響を与えない位 置に配置され，その移動は遠隔操作によるパルスモー夕 で駆動される。この方法により，対処療法的ではあるが 地震計の特性を復旧させることが可能となった。 


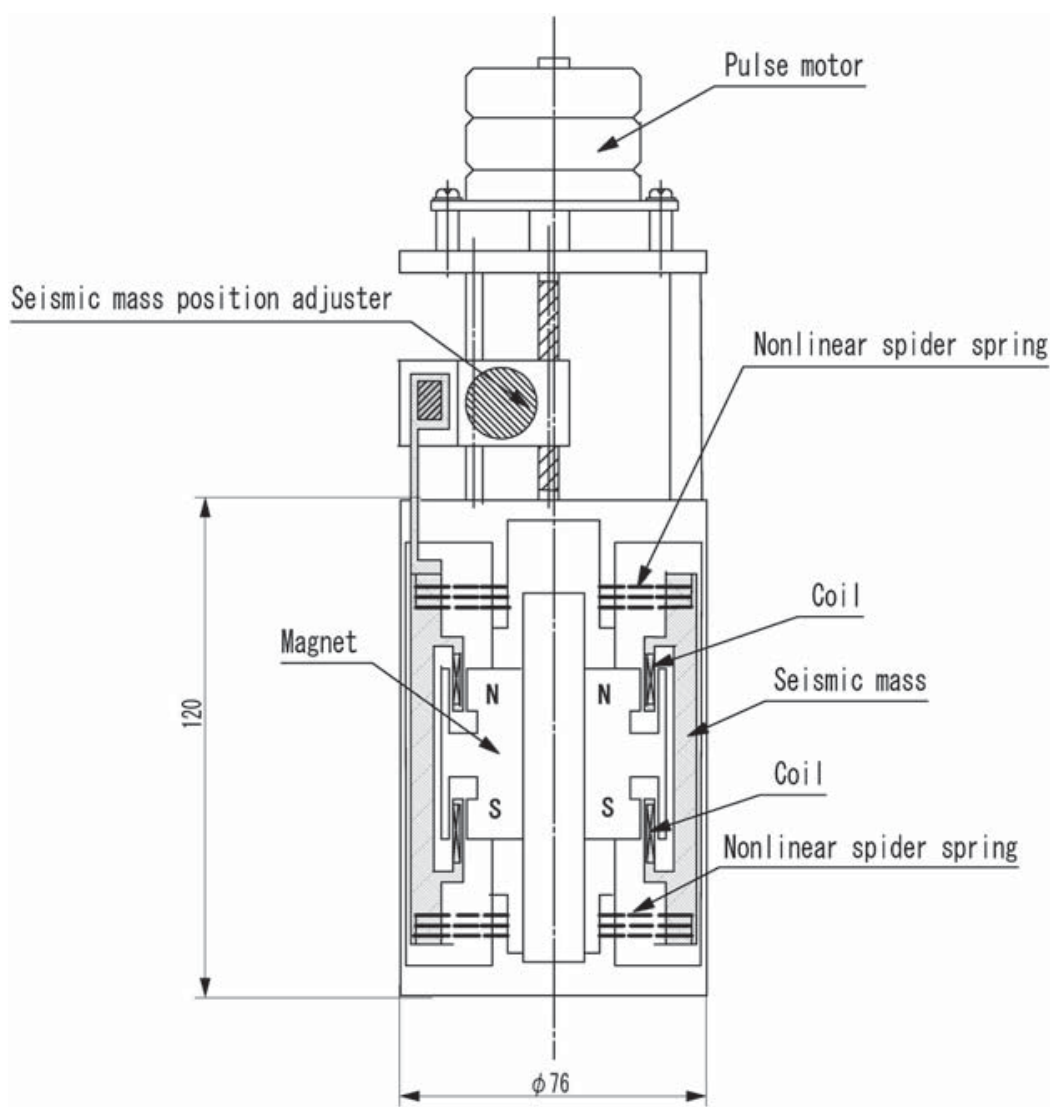

Fig. 1. Cross-sectional view of a borehole vertical seismometer with a natural frequency of $1 \mathrm{~Hz}$. The size is in mm unit.

このように，ボアホール用地震観測システムの開発に おいては，長期間の安定的観測を実施することが最大の 技術的課題であったため [明石・福尾 (1977), 高橋 (1982)]，地震計に採用された非線形ダイヤフラムばねそ のものに関する研究開発，性能評価は今日まで積極的に 行われてこなかった. 気象研究所地震火山研究部 (1980) は，海底地震計開発において採用した非線形ばねを利用 した地震計について評価を実施しているが, ばねのメカ ニズムについては詳しく述べていない. Yamada et al. (2009) は, 同様な非線形ダイヤフラムばねを使った月震 計 LUNER-A の特徵についてまとめているが, ばねの 支持機構については概略が紹介されているのみである. L-4C 地震計に関しては, 西村 (1990) や Riedesel et al. (1990)により, その性能が評価されているほか, 増幅器 などを付け加えて広带域化を図る事例がWebb et al. (2001)により紹介されている.

現在, Hi-net をはじめとする基盤的地震観測網の展開 により，比較的容易に地震波形を入手することが可能に
なったが，地震計で観測された記録を詳細に解析する際 には，その地震計の特性や観測限界について十分に理解 しておくことが必要である。とりわけ，上下動成分のば ねは水平動成分と異なり，振動による動的負荷の他に振 子質量を支えている静的負荷が常時加算されるため, 静 たわみ等の問題により，長期的には性能の劣化を生じる 可能性が高く，特に高温環境下ではクリープに伴うばね 性能の低下が加速され，技術的課題が大きい。 そこで本 論文では, 深層ボアホールを含む Hi-netで使用されて いる $1 \mathrm{~Hz}$ 上下動地震計の非線形ダイヤフラムばねと, それによって支えられている振子の動特性について，解 析及び考察を行う

\section{§2. 非線形ダイヤフラムばねの特性}

\section{1 非線形ダイヤフラムばねとは}

Hi-net 等で用いられている $1 \mathrm{~Hz}$ 上下動地震計 (Fig. 1) では，上下各 3 枚, 計 6 枚の非線形ダイヤフラムばねが, 可動コイルを含む比較的重い振子の錘（約 $1 \mathrm{~kg}$ ）を支え 
ている[Johnson (1969)]。この非線形ダイヤフラムばね とは, 内周リングと外周リングの間を円弧状の梁 3 本で 結合したもので, あらかじめ可動軸方向に初期変形が与 えられている (Fig. 2).ばねを動作中立点である平坦位 置まで押し縮めた時，同じ平面形状，同じ板厚の平坦の ばねと比べ，非常に弱いばね定数を持つ非線形ばねとな る。ここで，非線形ばねとは，変位の関数としてばね定 数が変化するばねを指す。なお，Fig. 2 に示す形状のば ねは，これまでも様々な呼び方が使用されているが，本 論文では非線形特性を持ったダイヤフラムばね［古川 (1966)）と言う意味で,「非線形ダイヤフラムばね」の名 称を採用する。な敃海外の特許や論文に扔いては “Spider Spring”と記載されることが多い [Johnson (1969), Chen and Dalton (1983)].

Fig. 3 に，非線形ダイヤフラムばねの代表的な特性,
および上下動振子として使われる線形ばねや長周期地震 計で利用されてきたゼロ・レングスばね [Aki and Richards (2002)] の特性を比較して示す. 同じ振子質量を支 持した場合，ゼロ・レングスばねや非線形ダイヤフラム ばねの静的変位量（伸び量）は, 線形ばねの静的変位量 に比べて小さい。ばね定数は, 同じ振子質量による負荷 を保持する動作中立点での荷重-変位曲線の傾きとして 定義されるが，振子質量やばね定数が同じでも，つまり 固有振動数が同じであっても, 振子質量が動作中立点に 達するまでのばねの静的変位量（静たわ久量）がばねの 種類によって異なる。例えば, ゼロ・レングスばねや非 線形ダイヤフラムばねを利用すれば，比較的小さな静た わみ量で済む上下動振子が実現可能である。このこと は，同じ質量の振子でも非線形ばねの弱いばね部を使う と振子の長周期化が可能となることを示すとともに，こ
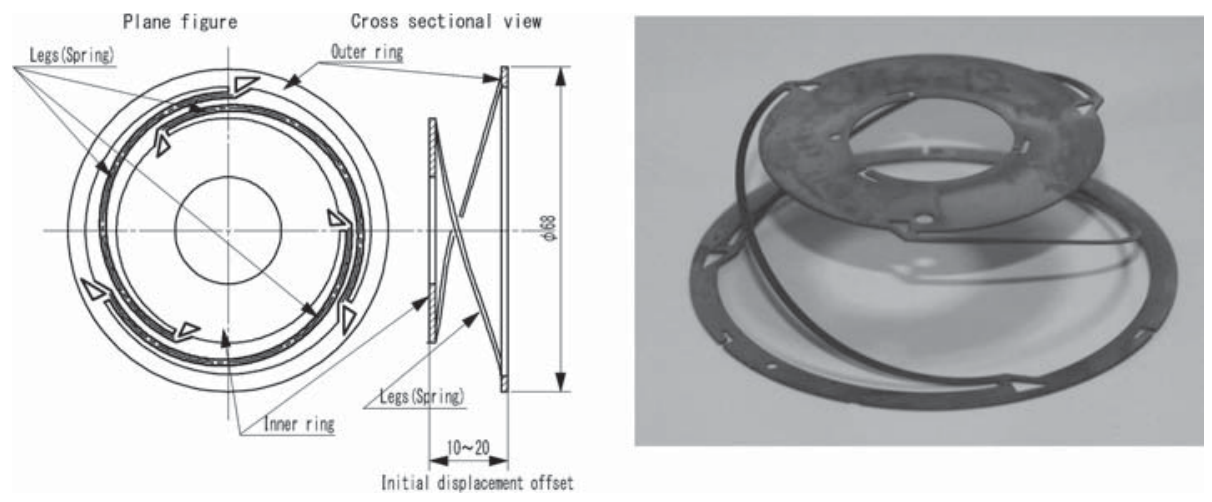

Fig. 2. Front and cross-sectional view (left) and photograph (right) of a nonlinear spider spring. The size is in mm unit.

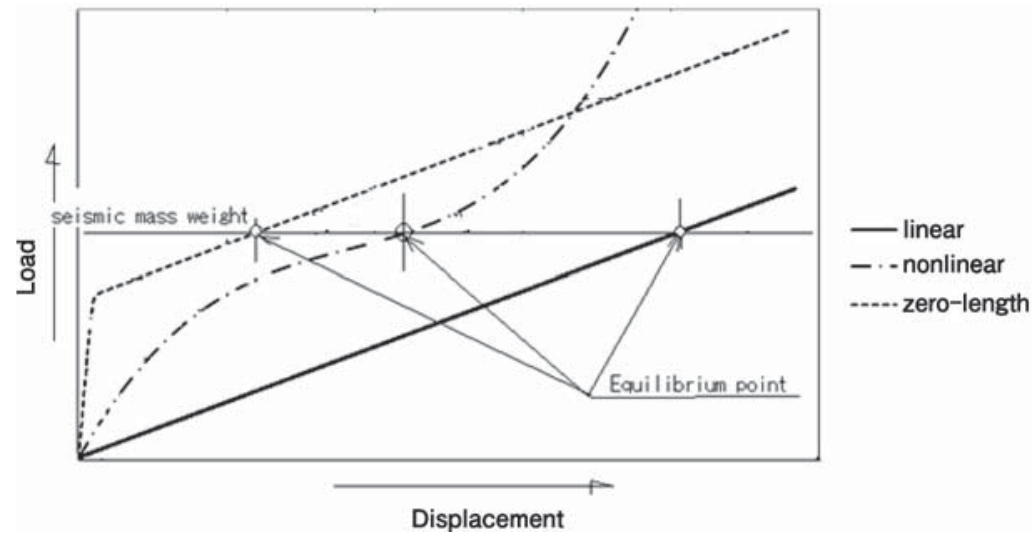

Fig. 3. Examples of spring properties in terms of the relation between load and displacement, for a linear spring (solid line), nonlinear spider spring (broken line), and zero-length spring (dotted line). Black circle is the equilibrium point for a nonlinear spider spring. 
れらのばねを選択することで地震計の小型化が可能とな ることを意味する。また，非線形ダイヤフラムばねは振 子を支持するだけでなく，振子の動きを一定方向に制限 するガイドとしての役割も果たす。

\section{2 初期変形を有するばねの成型と特性}

非線形ダイヤフラムばねを成型するためには，まず線 形ばねの理論式から得られる值 [Chen and Dalton (1983)] を第一近似として梁部分の幾何学的寸法を決定し, エッ チングにより平板から切りだされた平坦なダイヤフラム ばねを製作する。次に，その平坦なばねを数枚重ねて治 具に固定し, ダイヤフラムの外周リングと内周リングの 間に所定のオフセットを生じさせる，これにより，内周 と外周をつなぐ 3 本のばねとしての梁部は初期変形が与 えられた状態となる。この状態で熱処理することによ り, 応力的にもなだらかな安定した非線形ばねを作るこ とができる。

成型された非線形ダイヤフラムばねは，錘を順次載せ ていくとばねが平坦になる付近で急激にばねが弱くな り，さらに荷重を加えるとばねは再び硬くなる。この 非線形ダイヤフラムばねの荷重-変位特性データは, 初 期変形が与えられたばねを荷重計に載せ，ばね上端面に 荷重を加えながら徐々に押し下げ，その過程における各 変位量と荷重計の指示值を記録することで得られる.

Fig. 4 に実験の様子を示すとともに，荷重-変位特性 データを中立点が原点となるように座標変換した結果を Fig. 5 に示す。非線形ばねの特性はばねが平坦になるま で負荷質量を載せた状態で自由振動させて固有振動数を 測定することで得られる。 その固有振動数が所期の目標 值の許容範囲内であれば，その時の負荷質量を記録して
ばねを選別していく。

実測した非線形ばねの荷重-変位特性は, 相関係数 0.98 以上で 3 次曲線に近似する。堀内・他 (1997) は, 初 期変形のあるダイヤフラムばねの FEM 解析から, 荷重 と変位の関係は変曲点に対して点対称となる 3 次曲線で 表現可能であることを示した。このことから，ばねの特 性を表す上で，3 次曲線を用いた近似が妥当であると言 える．実際の変形を考えると，Fig. 2 に示すダイヤフラ ムばねの外周を固定し内周を押し下げると, 内周は回転 しながら下がるが，平坦位置を通過してさらに押し下げ ると初期変形の大小にかかわることなく平坦位置を境に その回転方向は反転する。 この現象は Fig. 2 で示される 3 本のはりが内周と外周の間に円弧状に張られている構 造において，各はりの両端が内周部と外周部に拘束され ている結果であり, この回転方向の反転が, 平坦位置を 対称点とするような変曲点をもつ変位-荷重特性（Fig. 5）となる原因となっている。この回転しながら平坦位 置まで変形する領域が振子質量を保持する 3 次曲線上で の硬いばねの領域であり，振子質量を保持し釣り合って 平坦となった位置は弱いばねの領域となっている。した がってこの平坦位置付近の弱いばねを振子の復元力とし て利用し，この付近を振子の動作点となるように組み立 てることで低固有振動数の振子系を実現することができ る。一方ばね定数は荷重-変位の関係式を微分して得ら れ（Fig. 6), 低固有振動数振子用ばねは，最下端（中立 点付近）の弱いばねとなる部分を利用していることにな る。

\section{3 高温環境下でのばね材料の選定とその特性}

高温環境下で長期間安定した高感度地震観測を行うた

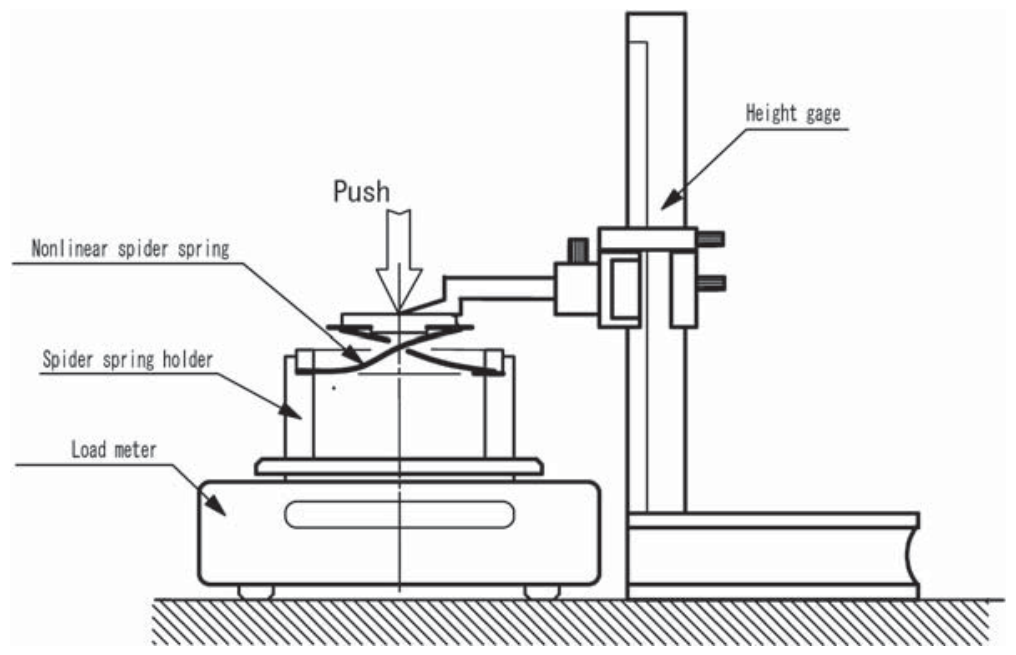

Fig. 4. Measurement of spring properties in terms of the relation between load and displacement. 


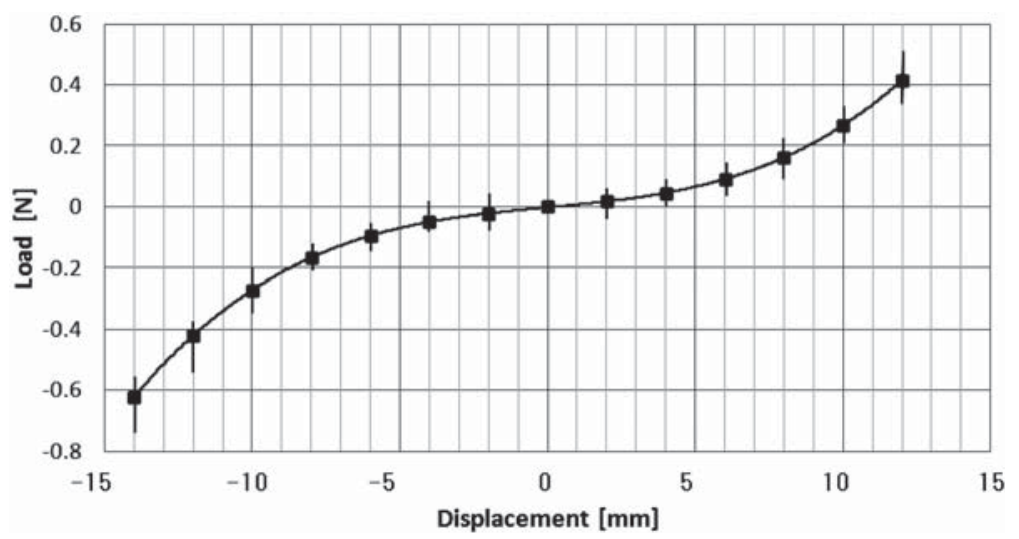

Fig. 5. Spring properties in terms of the relation between load and displacement for a nonlinear spider spring made of Beryllium-Copper (initial offset $21 \mathrm{~mm}$ ). The origin of the coordinates corresponds to the equilibrium point. Squares indicate averaged measurement values; solid line is the third-order polynomial regression line. The short bar shows the dispersion of measurements.

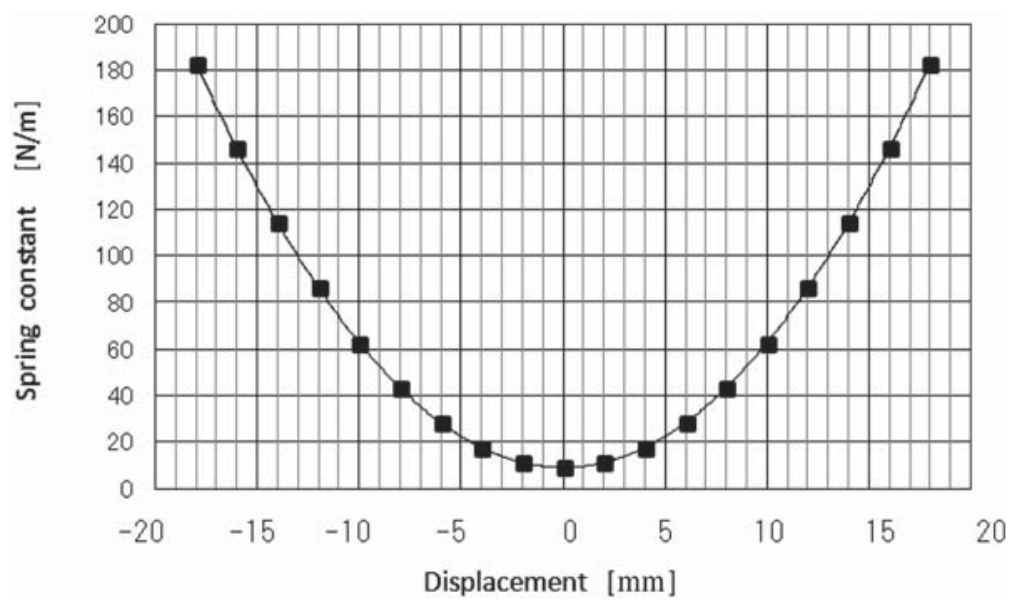

Fig. 6. Spring constant versus displacement of a nonlinear spider spring from the equilibrium point. Squares indicate averaged measurement values; solid line is the second-order polynomial regression line.

めには, 温度特性の良い, すなわち, 温度の影響が少な いばねを選ぶことが, 本質的に重要である。高温用のば ねの材料で現状入手可能なものとして, 温度係数の小さ な恒弾性材料, 及び高応力に耐える高弾性材料に注目し た.これらについては, 振子型重力計の開発において 1960 年代より研究が進んでいるが, 材料の安定性など に問題があり技術的課題が多く残っている[友田・他 (1985)］，そこで, いくつかの高弾性・恒弾性材料に対 し, 異なる初期変形量を有する非線形ダイヤフラムばね を成型し, ばねの荷重一変位特性の測定を行うとともに, その結果について, 従来のベリリウム銅と同様な非線形
ばねに適用できるかを検討した。なお，これらのばね材 料は, 地震計内部に組み込まれている磁石の影響を避け るため, 非磁性であることも必須の条件である.

高弾性材料の 1 つに, 非磁性で高強度・高強勒性を有 する合金であるパワーフロイ（(財) 電気磁気材料研究所

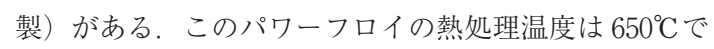
あり, 従来ばね材料として多く使われているべリリウム 銅の熱処理温度 $315^{\circ} \mathrm{C}$ の 2 倍以上の高温で時効硬化処理 を行う。また, ベリリウム銅より引張り強度が約 1.5 倍 あることも内部応力の開放を阻止する力となるため, 高 温環境下でのばねの安定性の向上が期待される[電気磁 
気材料研究所 (2010)]。さらに, 高温特性の指標となる 熱膨張係数およびばねの特性に直結するヤング率の温度 係数について，パワーフロイはいずれもべリリウム銅の 約 $1 / 2$ であることから，高温環境で使用するばね材料と して適していると言える。パワーフロイとベリリウム銅 の特性を Table 1 に示す.

このパワーフロイを使用し，初期変形量の目標值をそ れぞれ $0,10,15,20 \mathrm{~mm}$ に設定し熱処理を施した 4 種類 の非線形ダイヤフラムばねを成型した，Fig. 7 にこの 4 種類の初期変形量の異なるばね群（熱処理後の各ばねグ ループの初期変形量の実測值の平均はそれぞれ0, 8.9, 13.6, $18.3 \mathrm{~mm}$ ）の荷重-変位特性を示す. 初期変形を与 えていない平坦なダイヤフラムばねについても同様に測 定した結果, 荷重と変位の関係は, 線形成分は大きいも のの 3 次曲線で近似できる. 各特性曲線を微分して得ら れるばね定数は, 初期変形量によらずほぼ同じ形状の 2
次曲線となる (Fig. 8)，それぞれの差はゼ口点の位置で の最小ばね定数のみであり, 復元力として作用するばね 力は，すべて同様な非線形特性を示している。また，初 期変形量と最小ばね定数（振子動作点でのばね定数）の 関係は 1 次式で近似できる（Fig. 9).ただし Fig. 9 にお いて初期変形があるばねと全く初期変形を与えていない ばねとでは, 動作点付近におけるばねの内部応力の存在 が異なるため, モデルとしても別のものを考える必要が あり,ここでは初期変形のないばねのデー夕は参考值と してプロットし直線近似式からは除いた。

$$
k=-\beta y_{s}+\delta
$$

$k$ : 非線形ダイヤフラムばね動作点での最小ばね定数 $y_{s}:$ 非線形ダイヤフラムばねの初期変形量

$\beta:$ ば材の弾性係数と形状で決まる比例定数

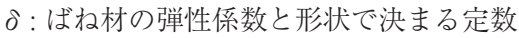

ここでばねの初期変形における (1) 式の物理的意味に

Table 1. Elastic and thermal characteristics of Power-fulloy and BerylliumCopper

\begin{tabular}{lcc}
\hline & Power-fulloy & Beryllium-Copper \\
\hline Tensile strength $\sigma_{\mathrm{T}}$ & $1.96 \times 10^{9} \mathrm{~N} / \mathrm{m}^{2}$ & $1.32 \times 10^{9} \mathrm{~N} / \mathrm{m}^{2}$ \\
\hline Young's modulus $E$ & $1.55 \times 10^{11} \mathrm{~N} / \mathrm{m}^{2}$ & $1.27 \times 10^{11} \mathrm{~N} / \mathrm{m}^{2}$ \\
\hline $\begin{array}{l}\text { Temperature coefficient of } \\
\text { Young's modulus }\end{array}$ & $-25 \times 10^{-5} / \mathrm{K}$ & $-51 \times 10^{-5} / \mathrm{K}$ \\
\hline Thermal expansion coefficient & $8 \sim 9 \times 10^{-6} / \mathrm{K}$ & $17.8 \times 10^{-6} / \mathrm{K}$ \\
\hline
\end{tabular}

After Research Institute for Electric \& Magnetic Material (2010) and NGK Insulators LTD.

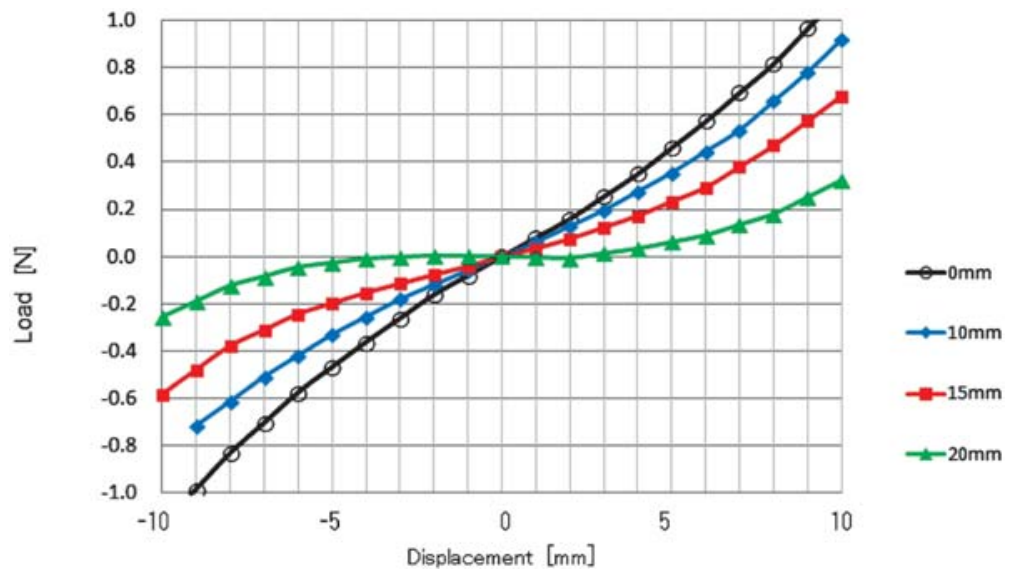

Fig. 7. Comparison of spring properties between load and displacement for various displacement offsets. Circle, blue diamond, red square, and green triangle are the averaged measurement values for a spring with an target initial offset of $0,10,15$, and $20 \mathrm{~mm}$, respectively. 


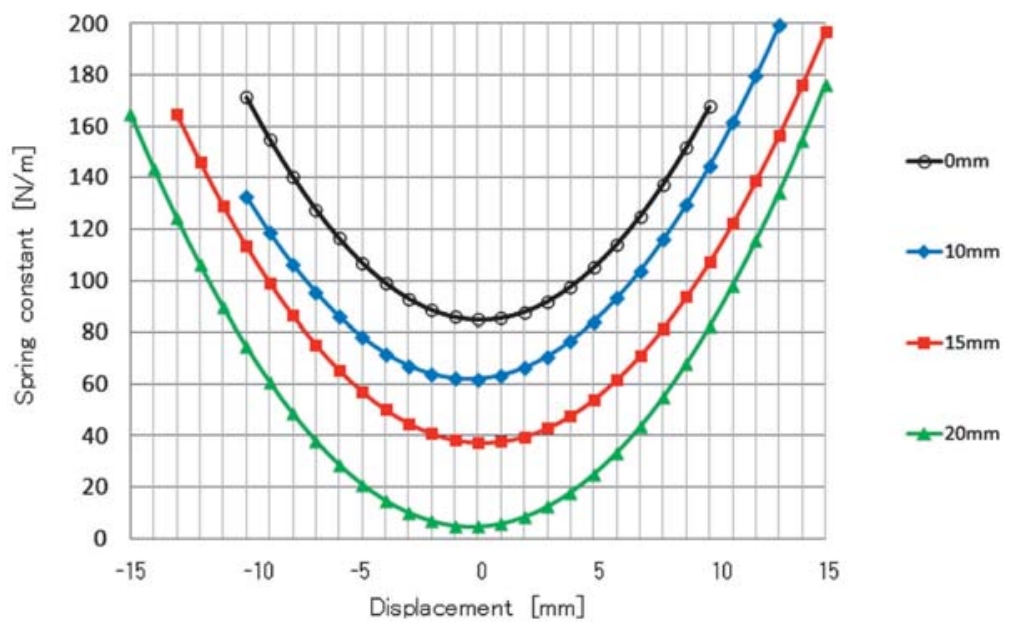

Fig. 8. Comparison of spring constants for nonlinear spider springs with various displacement offsets. Circle, blue diamond, red square, and green triangle are the averaged measurement values for a spring with an target initial offset of $0,10,15$, and $20 \mathrm{~mm}$, respectively.

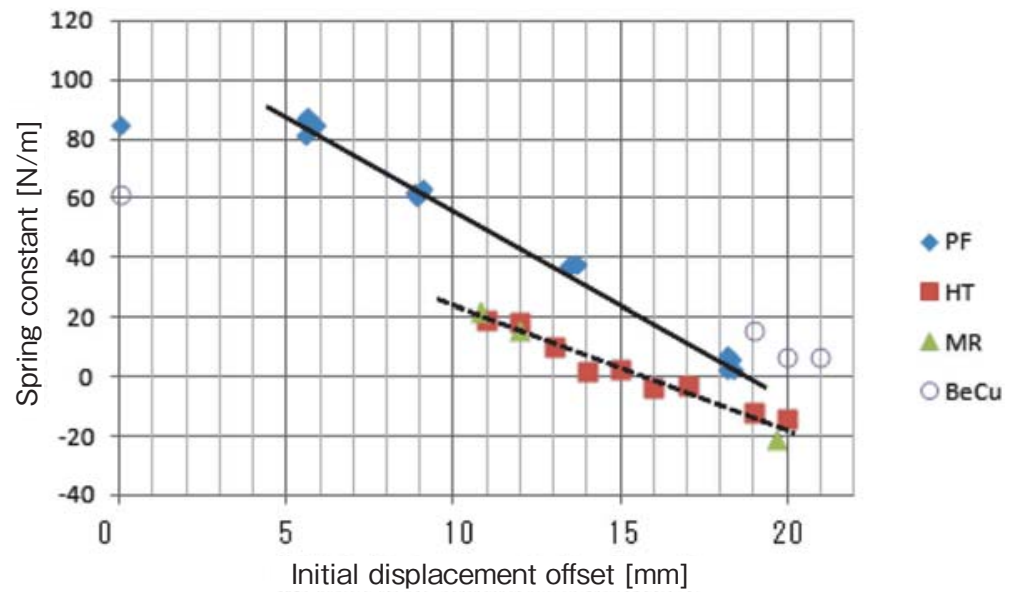

Fig. 9. Relation between the initial displacement offsets of spider springs and the minimum spring constants. PF: Power-fulloy (blue diamond), HT: Hitelinvar (red square), MR: Mangalloy (green triangle), BeCu: Beryllium-Copper (circle).

ついて考える。初期変形量 $y_{s}$ がゼロになるまで押し縮 められた位置で振子のばねとして機能することは, ばね 内部に初期変形をゼロにする過程で蓄えられた歪エネル ギーが振子質量を動作点に保持するためのエネルギーと なることを示す。これは，ゼロ・レングスばね内部の歪 エネルギーが動作点に至るまで振子質量を保持する力と なるのと同じ効果を果たしているとも言える.

エリンバー合金であるハイテリンバ（高温まで恒弾性 率), マンガロイ (恒弾性率), さらに常温で使用される ベリリウム銅についても，ダイヤフラムばねを成型し，
同様の実験を行ったところ, これらの素材でも初期変形 量と最小ばね定数の関係は 1 次式で近似できる関係に あった（Fig. 9).

初期変形量と最小ばね定数が線形 1 次の関係にあるこ とは，最小ばね定数の目標值を設定した場合に，材料ご とに初期変形量の設計值が決定されることを示してお り，非線形ばねの設計および製作が容易になることを示 している。なお，通常の直動型地震計の場合は，最小ば ね定数が正の值をとるように初期変形量が決定される が，最小ばね定数が０の場合は無定位の状態となり， 
フィードバック地震計などに利用することで小型の長周 期地震計開発の道を開くことも期待される.

\section{§3. 支持ばねの地震計への組込み}

\section{1 並列使用の利点}

高感度地震観測では，振子系における雑音を可能な限 り小さくすることが要求される。振子の質量に関して は，空気中のブラウン運動の影響を極力低減化させるた め, $1 \mathrm{~kg}$ 程度の質量が必要とされる [Aki and Richards (1980)].

そのため, Hi-net 等で使用される上下動地震計では, 所定の特性を有する非線形ダイヤフラムばねが 1 枚当た りは約 $0.17 \mathrm{~kg}$ を支持できるため,このばねを 6 枚使用 して必要とする質量を保持する構造となっている。この 地震計を構成する 6 枚のばねは，2.2 節で述べたように 固有振動数が揃ったばねの負荷質量の総和が目標の振子 質量（約 $1 \mathrm{~kg} ） に 一$ 致するように選択される.

このような地震計の構造は，ばねそれぞれに加わる応 力を低減する効果を有する。つまり，複数のばねを並列 に配置すると, 系全体のばね定数は個々のばね定数の合 計となるため, 1 枚の厚いばねでも，複数枚の薄いばね でも，合計のばね定数が同じであれば，負荷に対する変 位量は同じとなる。しかし，ばね表面の応力は変位量と ばねの厚さに比例するため，薄いばねを並列使用するこ とにより個々のばねにおける応力が低減される。その結 果, ばねの疲労などの進行を抑えて安定性が向上する.

実際の非線形ダイヤフラムばねの成型では，様々な要 因によって中立点付近のばね定数に多少のばらつきが生 じ，目標值通りに精度良く製作することは難しい。 この 問題に対し, Johnson (1969) は, 非線形ダイヤフラムば ねを複数枚並列に使用することで，所定のばね定数を得 る方法を提案した。つまり，単一の精密な特性のばねを 製作するよりも，目標值に近い特性でばらつく複数枚の ばねを組み合わせて所定の特性を得る方が生産性も良 く, 調整の自由度が増し, より実用的であるためである. このことは，ばね製作工程を容易とし，コストを下げる 利点も有する。

\section{2 ばね過拘束とその軽減}

複数枚のダイヤフラムばねを使用すると，その 3 倍の 本数の梁で振子質量を支持する形となる。 しかし，エッ チングの部位による反応速度の差異, ダイヤフラムばね の製造上の理由による各梁部の長さの微小なばらつきや わずかな組立誤差が振子の動きに対して構造上過拘束と なり，振子の滑らかな動きを阻害する。そのため，振子 の動きが不自然となり，所定のばね定数より硬いばね定 数となることも多い，多数枚のばねの並列使用では最悪
のケースで微小振動に応答しない事も生じてしまう。こ のようなばねの過拘束を軽減するため, この種の地震計 の設計では，ばねの全ての端末を完全には固定せず，一 方の端を摩擦接触にしてばねの過拘束の一部を解放し, 微小振動時も滑らかな動きをするような配慮がなされて いる [Holmes (1973)].

以上の点に留意すれば，非線形ダイヤフラムばねを利 用した直動型上下動地震計を製作することが可能であ る。さらに，非線形ダイヤフラムばねを利用することに よって地震計の小型化が可能となるため, ボアホール設 置用の地震計として非常に有用である。

\section{§4. 非線形ばねの地震計の特性 4.1 振動数特性への影響}

本節では，非線形ばねを組み込んだ地震計の振動数特 性を調べる。非線形ダイヤフラムばねを振子系のばねと して用いる場合には，初期変形が平坦になるまで縮めた 最小ばね定数の位置を振子変位のゼロ点に移動したばね 定数の式を考えればよい。つまり，このばね定数の 2 次 式に振子の振動変位を掛けた值が地震計における振子の 復元力である

この非線形ばねにより支持された振子系において振子 質量を $m$, 減衰係数を $\lambda$, ばね定数を $k(x)$, 入力加速度 を $\ddot{y}$ ，振子の変位を $x$ とすると運動方程式は次式で表さ れる。

$m \ddot{x}+\lambda \dot{x}+k(x) x=-m \ddot{y}$

この (2) 式に Fig. 6 に示される非線形ばねのばね定数 の式

$k(x)=a x^{2}+c$

( $a, c$ は，ばねの材料と形状で決まる定数)

を代入すると，振子の運動方程式は

$\ddot{x}+(\lambda / m) \dot{x}+(a / m) x^{3}+(c / m) x=-\ddot{y}$

となる。 (4) 式は, 対称形復元力を有する粘性減衰系 のダフィング方程式の強制振動の式 [小堀 (1982)］とし て知られている。この方程式は非線形であるため, 振動 数応答特性は入力振幅の大きさに依存する。したがっ て，実際の非線形ばねを利用した地震計では，入力振幅 に対する応答特性を事前に評価するため，(4) 式を用い てこの振子の挙動を調べる.

$\lambda / m=2 h \omega_{0}$

ここで, $\omega_{0}^{2}=c / m, \omega_{0}=2 \pi f_{n}$ であるから，振子質量 $m=$ $1 \mathrm{~kg}$, 固有振動数 $f_{n}=1.17 \mathrm{~Hz}$, 減衰定数 $h=0.5$ の地震 計で, 約 $1 \mathrm{~Hz}$ 地震計用に製作され保持力が約 $0.17 \mathrm{~kg}$ の ばねの中から Fig. 6 に示す非線形ダイヤフラムばねを 6 枚並列に組み込んで使用する場合の総ばね定数 $(k=3.22$ $\times 10^{6} x^{2}+54.27 ）$ を用いてその応答を数值計算で求めた 


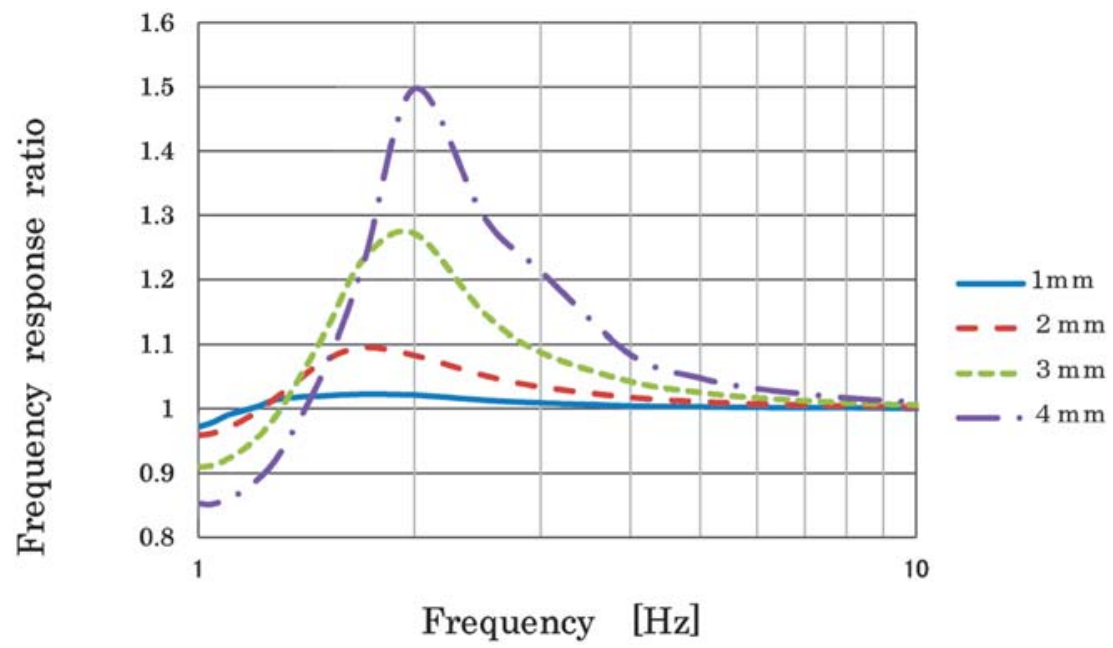

Fig. 10. Frequency response ratio of a vertical seismometer with input oscillation amplitudes of 1,2 , 3 , and $4 \mathrm{~mm}$.

[小堀 $(1982)]$.

入力変位を $1,2,3,4 \mathrm{~mm}$ とし, 各変位入力振幅に対す る振動数応答特性と線形ばね振子の応答特性の比を Fig. 10 に示す。これらの結果から，1 $\mathrm{mm}$ の入力では非線形 ばね使用による影響は無視できるが，入力変位の増大と ともに, 固有振動数付近の応答振幅特性が増大する。ま た，固有振動数の高振動数への転移により，振動数応答 曲線のピークが高周波数側に傾斜した背骨曲線 [神保・ 古川 (1964)］が顕著になる現象も生じさせることにな る.

以上から，このタイプの地震計は小振幅測定に適して いることがわかる，汐見・他 (2005) は, Hi-netで観測 された大振幅の振動を解析し，変位波形に変換した際に 片振幅で $1 \mathrm{~mm}$ 以上となる場合に，観測記録が異常であ る可能性が高いことを示した．Fig. 10 からも，波形歪 の影響から逃れるためには，1 $\mathrm{mm}$ の振動測定範囲内で 使用することが望ましいことが分かる，また，固有振動 数成分が含まれる波形では，当然のことながら過大入力 に留意することが必要である事を表している。一般的 に, 非線形振子は固有振動数付近でジャンプ現象や履歴 現象を起こすため, 非線形方程式特有の問題が発生する ことに留意する必要がある。したがって，測定範囲の検 討は事前に行うべきである。

\section{2 地震計の傾斜と固有振動数への影響}

次に, 非線形ダイヤフラムばねを組込んだ上下動地震 計が，鉛直軸に対して傾いた時の特性について述べる。 可動軸が鉛直方向に対して $\theta$ だけ傾斜すると，振子質量 に加わる可動軸方向の重力加速度成分は $g \cos \theta$ となる.
このため，振子の中立点がばね定数の硬い方向にわずか に上昇することになるとともに，固有振動数も高くな る. 実際に，振子の可動軸の傾斜によってばねに加わる 負荷が減少した時，その負荷の減少量に見合う振子の静 的変位量を Fig. 5 から読取り，その変位量を Fig. 6 のば ね定数と変位の関係式に当てはめると, 可動軸の傾斜に 見合う振子の静的変動に伴うばね定数の変化が計算でき る。 Fig. 11 にこのばね単体を測定した特性值から計算 した固有振動数と地震計の傾斜の関係を示す。 $\square$ 印は, $1 \mathrm{~Hz}$ 上下動地震計を実際に傾斜させた時の各傾斜角で の固有振動数の実測值であり，傾斜 3 度で $5 \%$, 5 度で は $10 \%$ 程度固有振動数が高くなる。一方，計算值に基 づく固有振動数の変化は, 実測值より有意に大きくなっ ているが，測定範囲を超える大きな変形領域では，モデ ル化した梁の仮定条件を逸脱し，3次式だけでは近似で きない変形を含んでいるためと思われる。

これまでHi-netのボアホール掘削に際しては，上下 動地震計に対する傾斜補正装置を含めていないため, 許 容傾斜角を 3 度以内としているが，傾斜角 3 度以内であ れば固有振動数の変化は $5 \%$ 以内に収まるという実験結 果は，ボアホール掘削における傾斜角の制限に対して一 定の根拠を与えたことを意味する。

\section{$\S 5$ ま と め}

多くの地震計で使用されている非線形ダイヤフラムば ねについて，実験および考察に基づいて，以下の特徴を 明らかにした。

1）非線形ダイヤフラムばねの最小ばね定数は，成型さ 


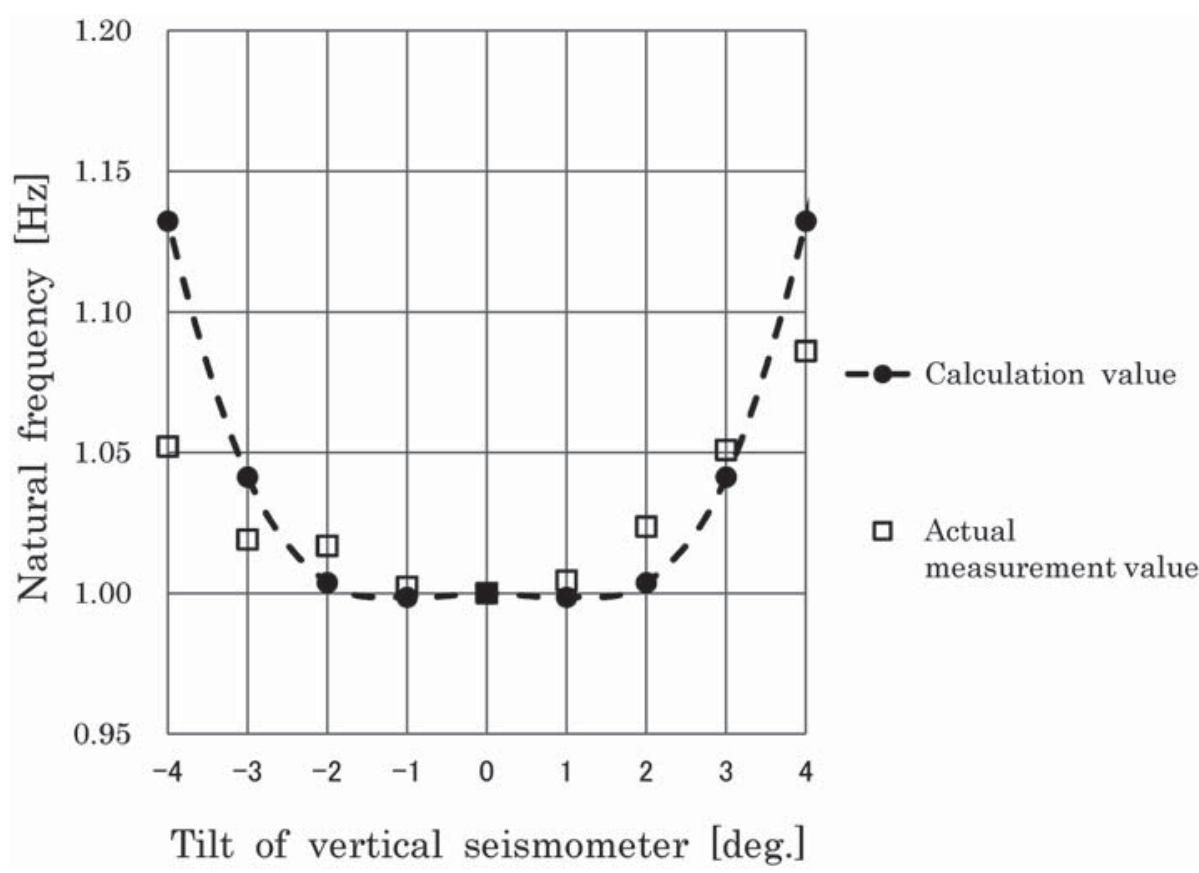

Fig. 11. Natural frequency shift caused by the tilt of a vertical seismometer. Squares and dashed line with circles indicate measured and calculated values, respectively.

れたばねの初期変形量とは線形の関係にあり，変形 量が大きければばね定数が小さくなる.

2）平坦なダイヤフラムに初期変形を与えて成型した非 線形ダイヤフラムばねは，その変位が動作点を中心 に対称であり，その中心を離れるに従い，2 次曲線 に乗る形でばね定数が強くなる，そのため，地震計 の傾斜とともに固有振動数が上昇する.

3）初期変形がない平坦なダイヤフラムばねにおいて も，動作点を中心に変位に対して 2 次曲線に乗る形 でばね定数が強くなり, 非線形ばねと同様な特性を 示した。

4）復元力としてのばね効果に関しては, 必ずしも初期 変形を与えられた非線形ばねだけが動作振幅に対し て非線形性を有するのでなく、ばね部分に対する 様々な機械的拘束により, 平坦なばねもある程度の 非線形特性を有していることを示している。

5）このことは, 非線形ばねの初期変形量だけが振幅に 対する非線形の原因ではなく, ダイヤフラムばねの 平面形状に起因するばね定数の変化であり, この種 のダイヤフラムばねを用いた直動型地震計から得ら れた振動デー夕を精密に解析する場合には, 非線形 ばね, 平坦ばねに関わりなく同様な配慮が必要であ ることを示唆している.
6）上記のようなばねに非線形特性があっても，標準仕 様の動作振幅内では，実用上十分線形特性と考えて も問題ない. しかし, 同時に振子の設計仕様を超え る過大入力があった時, それが固有振動数付近では 少なからぬ影響がある。

以上の結果は, 関係者には既知であっても漠然と認識 されていたことも多く, 今回の実験でそれらの現象の原 因を改めて明らかにできたと考えている.

観測デー夕の利用者は，本来，線形ばねを使用すべき ところに非線形ばねを採用し，近似的に線形とみなせる 極わずかな部分を利用していることを正しく認識した上 で，精密な地震波形解析を進めることが重要である。上 述の通り，非線形ダイヤフラムばねを振子のばねとして 利用することは, 特に上下動成分では非常に有効であ る。小型の地震計でも重い振子質量の振子系を構成でき るほか, その動作点付近では弱いばねとして作用するた め, 外乱や雑音に強く, 大きな増幅特性が得られる低固 有振動数の振子となる。逆に, 動作中立点に至るまでは 硬く強いばねとして機能するため, 線形ばねでは大きな 静たわみとなるところが小さな静たわみで済み, 地震計 の小型化や実質的なばね長の短縮とそれに伴うサージン グなどを起因とする高調波共振の排除など, 地震計とし ての特性向上を実現させている. 
今回, 高感度微小地震観測に数多く利用されている, $1 \mathrm{~Hz}$ 上下動地震計の主要部材のひとつである非線形夕゙ イヤフラムばねについて実験・解析を行ない,この非線 形ばねを使用した地震計の特性把握や使用上の問題点を 主眼に検討したが, 今後は他の地震計に使われている非 線形ばねの解析も行い, さらに設計側に必要となるばね の非線形特性の材料力学的見地からの検討も報告したい.

\section{謝辞}

ボアホール用上下動地震計の開発に当たっては, 防災 科学技術研究所（旧国立防災科学技術センター）の多く の方々, 及び高木章雄東北大学名誉教授にご協力, ご指 導をいただきました。また電気磁気材料研究所増本 健 理事長より新しいばね材料の提供と技術指導をいただき ました、また本稿を改善するにあたり匿名の査読者およ び加納靖之編集委員より有益なご指摘をいただきました 事に感謝いたします。

\section{文献}

明石和彦・福尾信平, 1977 , ボアホール型地震計及びひ ずみ計, 精密機械, 43, 111-117.

Aki, K. and P.G. Richards, 1980, Quantitative Seismology, Theory and Methods. Volume I, W.H. Freeman, San Francisco, 557pp.

Aki, K. and P.G. Richards, 2002, Quantitative Seismology, 2nd ed., University Science Books, Sausalito, 700pp.

Chen, S.J. and C. Dalton, 1983, Theoretical and experimental approaches to the geophone spurious frequency, Geophys. Prospect, 31, 574-590.

電気磁気材料研究所, 2010, 材料の諸特性, <http:// www.denjiken.or.jp/d-htm/business/property.html $>$, (参照 2010-2-15)

Forbes, C.B., R. Obenchain, and R.J. Swain, 1965, The LASA sensing system design, installation, and operation, IEEE, 53, 1834-1843.

古川英一, 1966, 振動および衝撃測定, 誠文堂新光社, 375pp.

Green, P.E., R.A. Frosch Jr., and C.F. Romney, 1965, Principles of an experimental large aperture seismic array (LASA), IEEE, 53, 1821-1833.

萩原尊禮, 1966, 地震の観測, 科学, 8 (7), 342-347.

Holmes, R.C. Jr., 1973, Seismometer with spring spider suspension, US Pat. 3718900.

堀内寛二・石坂昭夫 - 鹿熊英昭, 1997, 低周波振動計用 ダイヤフラムばねの解析, 精密工学会秋季学術講演論 文集, 2,371 .

神保泰雄・古川英一, 1964, 工業振動学演習, 学献社, 289pp.
Johnson, W.P., 1969, Spring suspension for a low-frequency geophone, US Pat. 3451040.

気象研究所地震火山研究部, 1980, 海底地震常時観測 シ ステムの開発，気象研究所技術報告， $4,39$.

小堀与一, 1982, 工業技術者のための微分方程式読本, 工学図書, 282pp.

黒田 徹・阿部 進, 1999, データ取得技術, 物理探査 ハンドブック 2: 手法編 1 章-4 章, 物理探査学会, $26-48$.

Lee, W.H.K., P. Jennings, C. Kisslinger, and H. Kanamori (Eds.), 2002, International Handbook of Earthquake \& Engineering Seismology, Part A, Volume 81A, Academic Press, 1200pp.

西村太志, 1990, L-4C 型短周期地震計の固有周波数と ダンピング定数の検定, 地震 $2 ， 43 ， 279-282$.

Obara, K., K. Kasahara, S. Hori, and Y. Okada, 2005, A densely distributed high-sensitivity seismograph network in Japan: Hi-net by National Research Institute for Earth Science and Disaster Prevention, Rev. Sci. Instrum., 76, 021301-1-021301-12, doi:10.1063/1.1854197.

Oliver, J. and L. Murphy, 1971, 'WWSSN : Seismology's global network of observing stations', Science, 174, 254-261.

Press, F., 1959, The need for fundamental research in seismology: A summary of the report of the panel on seismic improvement, Transactions, American Geophysical Union, 40, 212-221.

Riedesel, M.A., J.A. Orcutt, and R.D. Moore, 1990, Limits of sensitivity of inertial seismometers with velocity transducers and electronic amplifiers, Bull. Seism. Soc. Am., 80, 1725-1752.

汐見勝彦 - 小原一成・笠原敬司, 2005, 防災科研 Hi-net 地震計の飽和とその簡易測定, 地震 2, 57，451-461.

汐見勝彦 - 小原一成・針生義勝 - 松村 稔, 2009, 防災 科研 Hi-net の構築とその成果, 地震 2, 61 特集号, S1-S7.

高橋 博, 1970, 関東南部における異常地殼活動に関す る特別研究, 地震予知連絡会会報, 4, 40.

高橋 博, 1982, 深層観測によって明らかにされた関東 地方の微小地震活動の特性について, 国立防災科学技 術センター研究報告, 28, 1-104.

友田好文・鈴木弘道・土屋 淳 (編), 1985, 地球観測 ハンドブック, 東京大学出版会, 850pp.

Webb. S.C., T.K. Deaton, and J.C. Lemire, 2001, A broadband ocean-bottom seismometer system based on a $1-\mathrm{Hz}$ natural period geophone, Bull. Seism. Soc. Am., 91, 304-312.

Yamada, R., I. Yamada, H. Shiraishi, S. Tanaka, Y. Takagi, N. Kobayashi, N. Takeuchi, Y. Ishihara, H. Murakami, K. Yomogida, J. Koyama, A. Fujimura, and H. Mizutani, 2009, Capability of the penetrator seismometer system for lunar seismic event observation, Planetary and Space Science, 57, 751-763. 